OPEN ACCESS

Edited by:

Nicolas Pedrini,

National University of La

Plata, Argentina

Reviewed by:

Carla Huarte-Bonnet,

Instituto de Investigaciones

Bioquímicas de La Plata

(INIBIOLP), Argentina

Mavis Agyeiwaa Acheampong,

University of Ghana, Ghana

*Correspondence:

Joel da Cruz Couceiro

joel.couceiro@usp.br

Specialty section:

This article was submitted to

Fungi-Animal Interactions,

a section of the journal

Frontiers in Fungal Biology

Received: 23 December 2020

Accepted: 15 February 2021

Published: 08 March 2021

Citation:

Couceiro JC, Fatoretto MB,

Demétrio CGB, Meyling NV and Delalibera I Jr (2021) UV-B Radiation

Tolerance and

Temperature-Dependent Activity Within the Entomopathogenic Fungal

Genus Metarhizium in Brazil.

Front. Fungal Biol. 2:645737.

doi: 10.3389/ffunb.2021.645737

\section{UV-B Radiation Tolerance and Temperature-Dependent Activity Within the Entomopathogenic Fungal Genus Metarhizium in Brazil}

\author{
Joel da Cruz Couceiro ${ }^{1,2 *}$, Maíra Blumer Fatoretto ${ }^{3}$, Clarice Garcia Borges Demétrio ${ }^{3}$, \\ Nicolai Vitt Meyling ${ }^{2}$ and Ítalo Delalibera Jr. ${ }^{1}$ \\ 'Laboratory of Pathology and Microbial Control of Insects, Department of Entomology and Acarology, "Luiz de Queiroz" \\ College of Agriculture, University of São Paulo (ESALQ/USP), Piracicaba, Brazil, ${ }^{2}$ Section for Organismal Biology, \\ Department of Plant and Environmental Sciences, University of Copenhagen, Copenhagen, Denmark, ${ }^{3}$ Department of Exact \\ Sciences, "Luiz de Queiroz" College of Agriculture, University of São Paulo (ESALQ/USP), Piracicaba, Brazil
}

Metarhizium comprises a phylogenetically diverse genus of entomopathogenic fungi. In Brazil, Metarhizium anisopliae s.str. subclade Mani 2 is predominantly isolated from insects, while $M$. robertsii and $M$. brunneum mostly occur in the soil environment. Solar radiation and high temperatures are important abiotic factors that can be detrimental to fungal propagules. We hypothesized that among 12 Brazilian isolates of Metarhizium spp., M. anisopliae Mani $2(\mathrm{n}=6)$, being adapted to abiotic conditions of the phylloplane, is more tolerant to UV light and high temperatures than $M$. robertsii $(n=3)$ and $M$. brunneum $(\mathrm{n}=3$ ). Inoculum of each isolate was exposed to UV-B for up to $8 \mathrm{~h}$ and viability evaluated $48 \mathrm{~h}$ later. After $8 \mathrm{~h}$ under UV-B, most of the isolates had germination rates below $5 \%$. Discs of mycelia were incubated at different temperatures, and diameter of colonies were recorded for 12 days. Mycelia of $M$. robertsii isolates grew faster at 33 ${ }^{\circ} \mathrm{C}$, while $M$. anisopliae and $M$. brunneum grew most at $25^{\circ} \mathrm{C}$. Dry conidia were incubated at 20,25 or $40^{\circ} \mathrm{C}$ for 12 days, and then viabilities were examined. At $40{ }^{\circ} \mathrm{C}$, conidia of five $M$. anisopliae isolates were the most tolerant. In the three experiments, considerable intra- and inter-specific variability was detected. The results indicate that conclusions about tolerance to these abiotic factors should be made only at the isolate level.

Keywords: entomopathogenic fungus, Metarhizium, UV-B radiation, temperature, tolerance

\section{INTRODUCTION}

Several species within the fungal entomopathogenic genus Metarhizium Sorokin (Ascomycota: Hypocreales) occur worldwide in soils of natural and agricultural ecosystems (Jaronski, 2007; Lacey et al., 2015). Metarhizium is one of the main genera causing disease in insects (Hesketh et al., 2010). Mainly known for their action against insects, some species of this genus are also able to associate intimately with different plants as endophytes (Hu and St. Leger, 2002; Bruck, 2005; Wyrebek et al., 2011), in a relationship where the fungus can supply their plant hosts with nitrogen derived from insects (Behie et al., 2012, 2017; Behie and Bidochka, 2014; Barelli et al., 2016) as well as promote plant growth (Jaber and Enkerli, 2016a,b; Sasan and Bidochka, 2012). 
In agroecosystems, Metarhizium communities are diverse and relatively complex (e.g., Steinwender et al., 2014), and the different species exhibit patterns of spatial distribution. In Brazil, a large diversity of Metarhizium spp. has been documented in soils of both natural and agricultural habitats (Rezende et al., 2015; Botelho et al., 2019). Still, there is currently limited knowledge of the characteristics of the isolates of these species of Brazilian origin.

In soils of the Cerrado biome in Brazil, Rocha et al. (2013) found a great abundance of M. anisopliae s.l., and by sequencing the $5^{\prime} \mathrm{EF}-1 \alpha$ region of isolates from many areas of Brazil, Rezende et al. (2015) reported M. anisopliae s.str. haplotypes grouped in the subclades Mani 1, Mani 2, and Mani 3. Metarhizium robertsii Bischoff, Rehner \& Humber is the most widespread and abundant species in Brazil, easily isolated from soils of many biomes (Botelho et al., 2019), while in temperate regions such as Denmark, Metarhizium robertsii has been recovered in low abundance in an experimental agricultural field (Steinwender et al., 2014, 2015). In contrast, Metarhizium brunneum Petch was recovered as the most prevalent species in agricultural soils in Denmark, while it has a limited occurrence in Brazil (Steinwender et al., 2014; Kepler et al., 2015; Brunner-Mendoza et al., 2019).

Even though the three species, Metarhizium robertsii, Metarhizium brunneum, and Metarhizium anisopliae, seemingly occupy overlapping niches, acting as entomopathogens and being found in soils worldwide (Lacey et al., 2015), there is a notable ecological difference between their distribution in Brazil. Generally, only isolates of $M$. anisopliae subclade Mani 2 are obtained as natural infections of insects collected in field crops in Brazil (Rezende et al., 2015), evidencing that members of this subclade are predominantly adapted to explore insects as a resource. On the other hand, isolates of $M$. robertsii can infect and kill different taxa of insects in laboratory conditions, but this is rarely observed in field conditions in Brazil (Lopes et al., 2013). Frequently, $M$. robertsii establishes associations with plant roots, indicating that this species is well-adapted to the soil and rhizosphere environment (Sasan and Bidochka, 2012; Rezende et al., 2015). Similarly, M. brunneum occurs predominantly in soils and is associated with roots (Steinwender et al., 2014, 2015), and at least in temperate regions, it is generally not found infecting insects above ground naturally (Meyling et al., 2011).

Metarhizium spp. are commonly found in cultivated areas and are therefore considered to be adapted to agricultural habitats (Meyling and Eilenberg, 2007; Vega et al., 2012). Abiotic factors (e.g., solar radiation, temperature, humidity, wind) can significantly influence the development, survival, and distribution of entomopathogenic fungi in the environment (Inglis et al., 2001). Agricultural habitats have limited canopy cover and are therefore considered frequently exposed to relatively high solar radiation and temperature fluctuations (Bidochka et al., 2001; Vega et al., 2012). Intense exposure to solar radiation can be detrimental to any organism (Solomon, 2008). Four hours of exposure to UV-B light can be enough to considerably reduce colony development and conidial viability, as well as delay conidial germination and cause conidial inactivation of Metarhizium spp. isolates (Braga et al., 2001a,b,c).
Temperature is also an important factor affecting fungal propagules. Walstad et al. (1970) reported that the optimum temperature range for isolates of $M$. anisopliae s.l. was $25-30^{\circ} \mathrm{C}$, but most isolates could germinate and sporulate between 15 and $35^{\circ} \mathrm{C}$. Temperatures outside the latter range can decrease growth rates and reduce the virulence of Metarhizium isolates (Thomas and Jenkins, 1997; Ekesi et al., 1999; Inglis et al., 2001; Tumuhaise et al., 2018; Acheampong et al., 2020a).

Fungal propagules present above ground, such as in phylloplanes, are more exposed to the harmful effects of solar radiation and high temperatures than propagules in the soil environment. Therefore, it should be expected that natural selection will favor fungi that are more tolerant to these abiotic factors above ground as adaptive traits. Consequently, phylloplane-inhabiting fungal isolates are expected to exhibit higher survival rates than those inhabiting the soil after the same exposure time to UV light and high temperatures.

The adverse effects of these abiotic factors on entomopathogenic fungal isolates are considered significant obstacles to their application as biopesticides due to a reduced probability of establishing epizootics (Braga et al., 2001a). Moreover, tolerance to UV radiation or high temperatures may be responsible for the niche differentiation between the three Metarhizium species mentioned, i.e., M. anisopliae subclade Mani 2 acting mostly as an entomopathogen above ground, and $M$. brunneum and $M$. robertsii primarily associated with plant roots below ground.

Based on these assumptions, we selected isolates of the $M$. anisopliae subclade Mani 2, M. robertsii, and M. brunneum from different hosts and habitats in Brazil to evaluate their relative conidial survival after exposure to UV-B radiation, and conidial germination and mycelial growth rates under different temperature regimes. Information about these responses is useful for expanding the knowledge about the ecology of Metarhizium species and understanding how particular fungal isolates can survive under unfavorable abiotic conditions that can affect their abundance and distribution. It was expected that isolates of $M$. anisopliae subclade Mani 2 would exhibit the highest tolerance to UV-B radiation and elevated temperatures since the members of this subclade are most frequently found infecting insects above ground, thereby being more exposed to these abiotic factors. In contrast, $M$. robertsii and $M$. brunneum isolates, more often recovered from the soil environment and less exposed than $M$. anisopliae, would exhibit the lowest tolerance to UV-B and show the most activity at relatively low temperatures compared to $M$. anisopliae. Furthermore, isolates from lower latitudes of Brazil, where solar irradiation is stronger, and temperatures are usually high, should also be more tolerant to UV-B radiation and high temperatures than those from higher latitudes.

\section{MATERIALS AND METHODS}

\section{Fungal Isolates}

Twelve isolates of Metarhizium spp. (six of M. anisopliae subclade Mani 2, three of $M$. robertsii, and three of $M$. brunneum) were selected from the Entomopathogen Collection "Prof. Sérgio Batista Alves," of the Laboratory of Pathology and Microbial 
Control of Insects, at the Luiz de Queiroz College of Agriculture, University of São Paulo, Piracicaba, State of São Paulo, Brazil. Information about the collection site and origin of the isolates is shown in Table 1. Isolates ESALQ 1426 and ESALQ 1635 (M. robertsii) and all isolates of $M$. anisopliae were identified by Rezende et al. (2015). Isolate ESALQ 5168 (M. robertsii) and all isolates of M. brunneum were identified by Iwanicki (2015) and Iwanicki et al. (2019). Identification in all studies were based on sequencing of the $5^{\prime} \mathrm{EF}-1 \alpha$ region.

\section{Effect of UV-B Radiation Exposure}

The isolates were grown in Petri dishes containing culture medium PDAY-Potato Dextrose Agar (Difco Laboratories, Sparks, MD, USA) enriched with yeast extract $\left(2.5 \mathrm{~g} \mathrm{~L}^{-1}\right)$ (KASVI, São José dos Pinhais, PR, Brazil) - and held in B.O.D. incubator (Biological Oxygen Demand) for 10 days $\left(25 \pm 1^{\circ} \mathrm{C}\right.$, $12 \mathrm{~h}$ photophase). After this period, conidia were harvested to prepare suspensions of each isolate (concentration: $10^{6}$ conidia $\mathrm{mL}^{-1}$ ) using sterile distilled water plus $0.05 \%$ Tween 80 . Aliquots of $150 \mu \mathrm{L}$ were inoculated covering the four central quadrants of Rodac Petri dishes (Replicate Organism Detection and Counting, $60 \times 10 \mathrm{~mm}$; J Prolab, São José dos Pinhais, PR, Brazil) containing $5 \mathrm{~mL}$ of PDAY plus $0.1 \% \mathrm{v} / \mathrm{v}$ Derosal 500 SC (Carbendazim, Bayer CropScience, SP, Brazil), a fungicide that has fungistatic properties at low concentrations. The plates were kept open in a laminar flow cabinet until all the liquid evaporated.

The experiment was conducted in a wooden box with four fluorescent lamps UVB-313EL (Q-Lab Corporation, USA), with peak irradiation corresponding to a wavelength of $313 \mathrm{~nm}$ (equivalent to UV-B light) and mean irradiation values of 659.54 $\mathrm{mW} \mathrm{m} \mathrm{m}^{-2}$ or $2.38 \mathrm{~kJ} \mathrm{~m}^{-2}$. Before the exposure experiment, the lamps were turned on for $30 \mathrm{~min}$ to generate a stable irradiation level. The plates were then placed in the box and covered with an acetate sheet to prevent exposure to wavelengths below $290 \mathrm{~nm}$, which includes UV-C $(280 \mathrm{~nm})$. The temperature inside the box was $27 \pm 1^{\circ} \mathrm{C}$ during the experimental exposures. The experiment was performed using a randomized complete block design, in which all treatments were repeated three times at the same conditions. In each of the replicates (blocks), separate conidial suspensions of each isolate were prepared and used for inoculation in five plates of each isolate corresponding to each of the five exposure times $(0,2,4,6$, and $8 \mathrm{~h})$, totalizing 12 isolates $\times 5$ exposure time (hours) $\times 3$ blocks (replicates) $=180$ observations. Plates representing the control were not exposed to UV-B (time $=0 \mathrm{~h}$ ), while the other plates were exposed for $2,4,6$, or $8 \mathrm{~h}$ (irradiation doses corresponding to $4.76,9.52,14.28$, and $19.04 \mathrm{~kJ} \mathrm{~m}^{-2}$, respectively). Every $2 \mathrm{~h}$, the respective plate of each isolate was transferred to an incubator $\left(25 \pm 1^{\circ} \mathrm{C}, 12 \mathrm{~h}\right.$ photophase). The incubation time was $24 \mathrm{~h}$ for control plates (otherwise germination tubes grow and it becomes impossible to count germinated conidia) and $48 \mathrm{~h}$ for exposed plates to allow DNA repair and germination of conidia. Viabilities were then evaluated, counting germinated and non-germinated conidia under a light microscope and at least 200 conidia per plate; a propagule was considered germinated when the length of its germ tube was equal to or higher than its diameter.

\section{Effects of Temperature Mycelial Growth}

The isolates were cultivated in culture medium PDA (Potato Dextrose Agar; Difco Laboratories, Sparks, MD, USA) and held in B.O.D. incubator $\left(25 \pm 1^{\circ} \mathrm{C}, 12 \mathrm{~h}\right.$ photophase) for 3 days. After this period, mycelial discs $(\phi=1 \mathrm{~cm})$ were made using a cork borer and transferred to the center of new Petri dishes $(\phi=9 \mathrm{~cm})$ containing PDA. There were five plates (replicates) per treatment, consisting of 12 isolates at each of the five temperature regimes ( 5 plates $\times 5$ temperatures $=25$ plates per isolate). The plates were sealed with parafilm and incubated in B.O.D., in the dark, in five temperature regimes: $15^{\circ} \mathrm{C}$ constant, $20^{\circ} \mathrm{C}$ constant, $25^{\circ} \mathrm{C}$ constant, $33^{\circ} \mathrm{C}$ constant, and $33^{\circ} \mathrm{C}$ for $8 \mathrm{~h}$ and $20^{\circ} \mathrm{C}$ for $16 \mathrm{~h}$. A completely randomized design was used. Two orthogonal axes were drawn at the bottom of the plates to serve as a reference. The

TABLE 1 | List of isolates used in the study, all deposited in the Entomopathogen Collection "Prof. Sérgio Batista Alves," ESALQ/USP, Piracicaba, State of São Paulo, Brazil.

\begin{tabular}{|c|c|c|c|c|}
\hline Species & Isolate code & Origin & Collection site (City, State) & Latitude \\
\hline Metarhizium anisopliae & ESALQ 43 & Hemiptera: Cercopidae & Flexeiras, Alagoas & $9^{\circ} 16^{\prime} \mathrm{S}$ \\
\hline \multirow[t]{5}{*}{ s.str. subclade Mani 2} & ESALQ 1116 & Coleoptera: Scarabaeidae & Piracicaba, São Paulo & $22^{\circ} 43^{\prime} \mathrm{S}$ \\
\hline & ESALQ 1641 & Hemiptera: Cercopidae & Boca da Mata, Alagoas & $9^{\circ} 38^{\prime} \mathrm{S}$ \\
\hline & ESALQ 1076 & Meadow soil & Arapongas, Paraná & $23^{\circ} 25^{\prime} \mathrm{S}$ \\
\hline & ESALQ 1175 & Meadow soil & Córrego Rico, São Paulo & $21^{\circ} 15^{\prime} \mathrm{S}$ \\
\hline & ESALQ 1604 & $\begin{array}{l}\text { Biotech G, Biotech® Controle } \\
\text { Biológico (commercial isolate) }\end{array}$ & Unknown & Unknown \\
\hline \multirow[t]{3}{*}{ Metarhizium robertsii } & ESALQ 1426 & Soybean soil & Londrina, Paraná & $23^{\circ} 18^{\prime} \mathrm{S}$ \\
\hline & ESALQ 1635 & Native forest soil & Delmiro Gouveia, Alagoas & $9^{\circ} 23^{\prime} \mathrm{S}$ \\
\hline & ESALQ 5168 & Coleoptera: Scarabaeidae & Iracemápolis, São Paulo & $22^{\circ} 34^{\prime} \mathrm{S}$ \\
\hline \multirow[t]{3}{*}{ Metarhizium brunneum } & ESALQ 5022 & Sugarcane soil & Iracemápolis, São Paulo & $22^{\circ} 34^{\prime} \mathrm{S}$ \\
\hline & ESALQ 5286 & Sugarcane soil & Iracemápolis, São Paulo & $22^{\circ} 34^{\prime} \mathrm{S}$ \\
\hline & ESALQ 5181 & Sugarcane root & Iracemápolis, São Paulo & $22^{\circ} 34^{\prime} \mathrm{S}$ \\
\hline
\end{tabular}


diameter of the colonies was measured daily for 12 days using a ruler. The bioassay was repeated three times.

\section{Survival of Conidia}

Eleven isolates were cultivated on PDAY and placed in B.O.D. incubator $\left(25 \pm 1^{\circ} \mathrm{C}, 12 \mathrm{~h}\right.$ photophase), while the isolate ESALQ 1635 (M. robertsii), which exhibited poor sporulation on PDAY, was grown only on PDA. After 10 days, conidia were harvested with a spatula, dried in a desiccator with silica (relative humidity-RH $<20 \%$; water activity $-\mathrm{a}_{\mathrm{w}} \leq 0.3$ ) and placed in Eppendorf tubes, which were vacuum packed to avoid interference of humidity; each tube contained $0.1 \mathrm{~g}$ of pure conidia. There were three Eppendorf tubes (replicates) per treatment, consisting of 12 isolates for each temperature regime ( 3 tubes $\times 3$ temperatures $=9$ tubes per isolate). A completely randomized design was used. The tubes were placed in B.O.D. incubators in the dark at 20,25 , or $40^{\circ} \mathrm{C}$. After 12 days, the tubes were placed inside a laminar flow cabinet and kept open for $30 \mathrm{~min}$ to allow slow hydration of conidia and avoid imbibition damage. Later, viabilities were evaluated according to the protocol of Oliveira et al. (2015). Briefly, suspensions of each tube (concentration: $10^{6}$ conidia $\mathrm{mL}^{-1}$ ) were prepared, and aliquots of $150 \mu \mathrm{L}$ were inoculated in Rodac Petri dishes containing PDA with an antibiotic (Pentabiótico: $500 \mathrm{mg} \mathrm{L}^{-1}$; composed of benzathine benzylpenicillin, procaine benzylpenicillin, benzylpenicillin potassium, dihydrostreptomycin base, and streptomycin base) and a fungistatic $(0.1 \% \mathrm{v} / \mathrm{v}$ Derosal $500 \mathrm{SC})$, covering the four central quadrants; plates remained open in a laminar flow cabinet until all the liquid evaporated. The plates were then closed and incubated in B.O.D. $\left(25 \pm 1^{\circ} \mathrm{C}, 12 \mathrm{~h}\right.$ photophase $)$ for $24 \mathrm{~h}$, after which viabilities were analyzed by counting germinated conidia.

\section{Statistical Analyses}

For analyses of the three experiments' data, generalized linear models (GLMs) were used, allowing analysis of the normal and proportional responses, as long as the distribution is part of the exponential family (Nelder and Wedderburn, 1972).

All models were selected using the half-normal plot (Moral et al., 2017), and a likelihood-ratio test allowed us to compare similarities between isolates in different conditions (Demétrio et al., 2014; Fatoretto et al., 2018). In the UV-B experiment, the quasi-binomial model was proposed and allowed to capture any overdispersion present in the data (Demétrio et al., 2014). For the experiment of temperature affecting the survival of conidia, the theory of combined models was used, particularly the betabinomial model (Molenberghs et al., 2017). These models can capture the data's overdispersion and allow the addition of the random effects that model the correlation within individuals. The model was adjusted using the GAMLSS package (Rigby and Stasinopoulos, 2005). Modeling of mycelial growth data was performed considering normal data, the dependence of the parcels (plates) inside the same B.O.D. incubator, and between parcels, which were the measurements over time of the same plate. A model was designed for each temperature, considering measurements from the 4 th day. All analyses were performed using the software R (R Core Team, 2020).

\section{RESULTS}

\section{Effect of UV-B on Conidial Germination of Isolates}

Due to considerable variability in the data, the binomial model did not present a goodness-of-fit. The best fitted model was a quasi-binomial model with a quadratic linear predictor for exposure time. In this model, conidial viability is described by separate curves, in which each fungus has distinct initial proportions (different intercepts) and different slopes (decay form) for each time (Figure 1).

Germination of control plates (no UV-B exposure) ranged between 97 and 100\%. UV-B light had little effect on conidia germination after $2 \mathrm{~h}$ of exposure, and germination rates were still above $70 \%$ for all isolates after $4 \mathrm{~h}$. After $6 \mathrm{~h}$ of exposure, most of the isolates started to show a substantial decline in conidial germination. By the end of the experimental time ( $8 \mathrm{~h}$ of exposure), nine isolates exhibited germination below 5\% (Figure 1). Isolates $M$. robertsii ESALQ 1426, M. brunneum ESALQ 5181 and ESALQ 5286, and M. anisopliae ESALQ 1175 and ESALQ 1641 reached complete inactivation of conidia at $8 \mathrm{~h}$, while isolate $M$. robertsii ESALQ 1635 was the most tolerant to UV-B radiation, being the only isolate to retain more than $50 \%$ of germination after $8 \mathrm{~h}$.

Since some isolates exhibited similar curves, likelihood-ratio tests were conducted to identify possible similarities between their viability. Six groups were defined $(\alpha=0.05)$, in order of UV-B tolerance (highest to lowest): (i) M. robertsii ESALQ 1635; (ii) M. anisopliae ESALQ 1076; (iii) M. anisopliae ESALQ 1116; (iv) M. anisopliae isolates ESALQ 43, ESALQ 1175, and ESALQ 1604, M. robertsii isolates ESALQ 1426 and ESALQ 5168, and M. brunneum isolate ESALQ 5022; (v) M. brunneum isolates ESALQ 5181 and ESALQ 5286; and (vi) M. anisopliae ESALQ 1641 (Figure 1).

\section{Effect of Temperature on Mycelial Growth of Isolates}

The selected model for the analysis of mycelial growth of the 12 isolates at $15^{\circ} \mathrm{C}$ was a quadratic regression model; the hypothesis that it well-represents the data was accepted after performing the lack of fit test, considering the isolate as a factor and measurement day as a quadratic term $(P=$ 0.4058; Figure 2). Through a likelihood-ratio test to compare the slope (growth rate) and the intercept between curves, isolates were grouped according to their growth rate and/or intercept. The highest growth rates were achieved by isolates $M$. brunneum ESALQ 5181 and M. robertsii ESALQ 1426 (Group 1), followed by $M$. brunneum ESALQ 5022 (Group 2), $M$. robertsii ESALQ 5168 (Group 3), and ESALQ 1635 (Group 4). The six M. anisopliae isolates had the lowest growth rates at this temperature, although, comparing the curves, M. brunneum ESALQ 5286 was grouped with three of them (ESALQ 43, ESALQ 1641, and ESALQ 1116).

A fifth-degree polynomial model was selected for the temperature $20^{\circ} \mathrm{C}$ constant (hypothesis accepted against a whole model: $P=0.8095$; Figure 3 ). At this temperature, $M$. robertsii ESALQ 1426 and ESALQ 5168 had the highest growth 


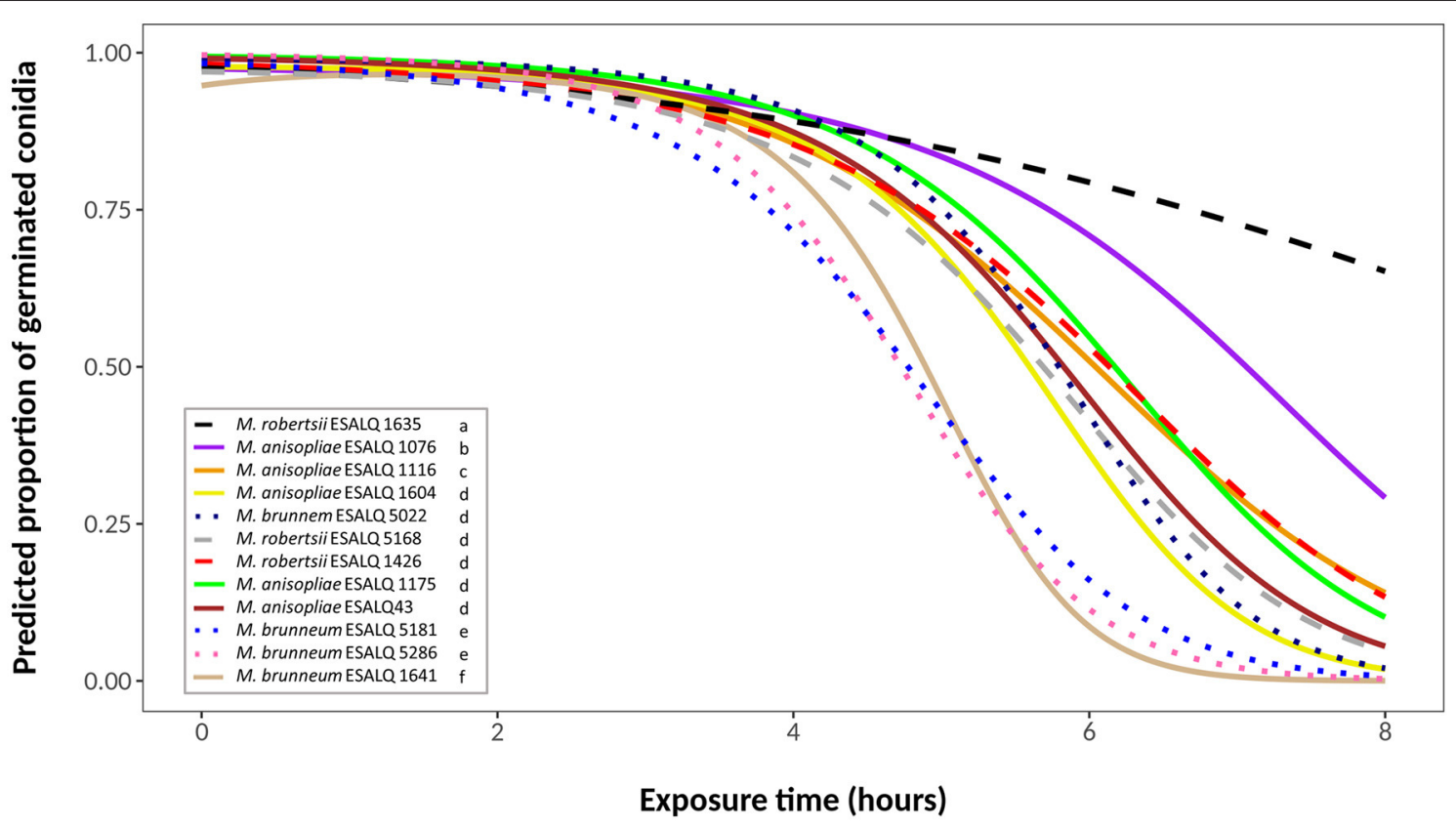

FIGURE 1 | Predicted proportion of germinated conidia of isolates of Metarhizium robertsii, M. brunneum, and M. anisopliae s.str. Mani 2 after UV-B exposure for 2, 4, 6 or $8 \mathrm{~h}$, adopting a quasi-binomial model with logit link function ( $\alpha=0.05 \%$ ).

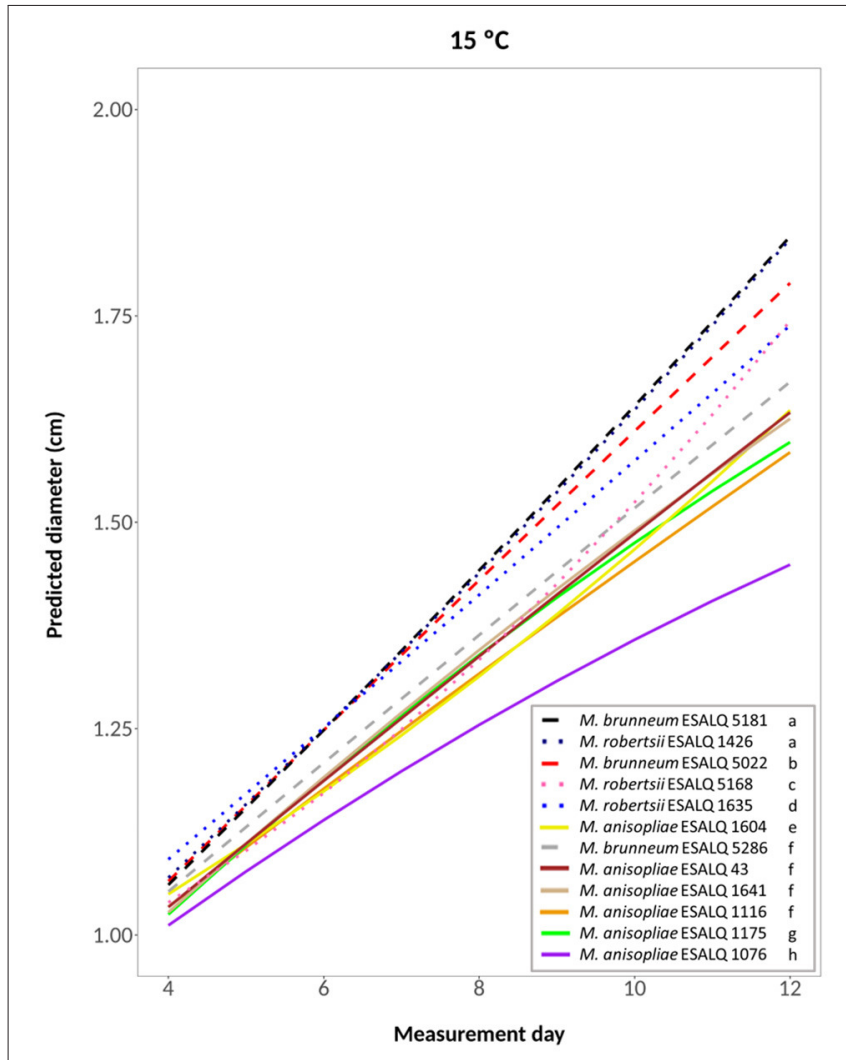

FIGURE 2 | Predicted diameter of colonies of isolates of Metarhizium robertsii, M. brunneum, and $M$. anisopliae s.str. Mani 2 after 12 days at $15^{\circ} \mathrm{C}$ constant, adopting a quadratic model ( $\alpha=0.05 \%)$.

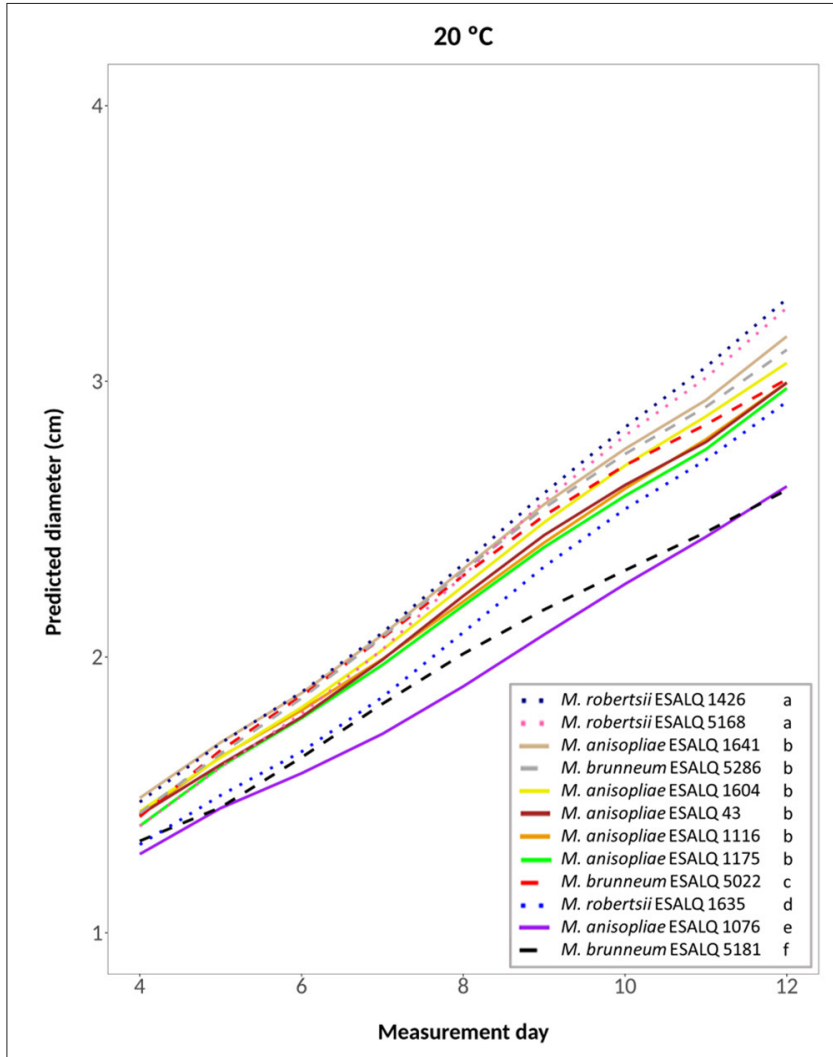

FIGURE 3 | Predicted diameter of colonies of isolates of Metarhizium robertsii, M. brunneum, and $M$. anisopliae s.str. Mani 2 after 12 days at $20^{\circ} \mathrm{C}$ constant, adopting a fifth-degree polynomial model $(\alpha=0.05 \%)$. 


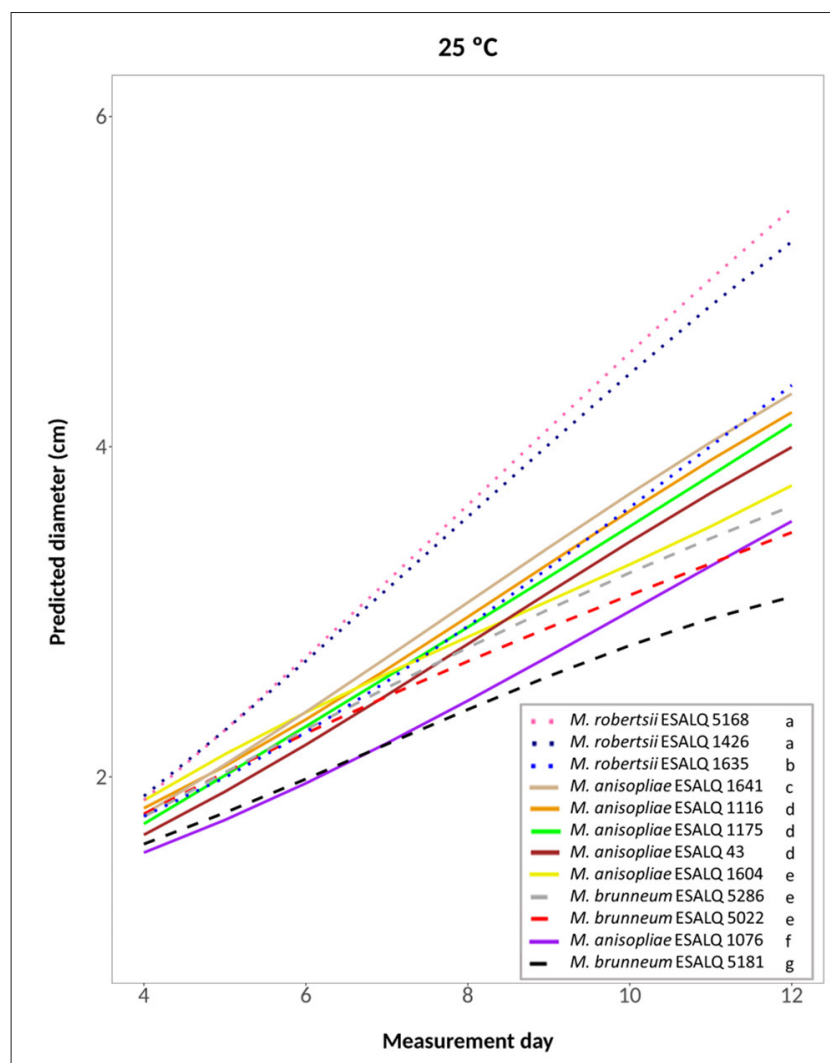

FIGURE 4 | Predicted diameter of colonies of isolates of Metarhizium robertsii, M. brunneum, and $M$. anisopliae s.str. Mani 2 after 12 days at $25^{\circ} \mathrm{C}$ constant, adopting a cubic model $(\alpha=0.05 \%)$. rates, being grouped. Six other isolates were also grouped: M. brunneum ESALQ 5286 and M. anisopliae ESALQ 1641, ESALQ 1604, ESALQ 43, ESALQ 1175, and ESALQ 1116. The other isolates were considered individual groups. Growth was lowest for M. anisopliae ESALQ 1076 and M. brunneum ESALQ 5181.

A cubic model was selected for the treatments at $25^{\circ} \mathrm{C}$ constant, at $33^{\circ} \mathrm{C}$ constant and the one alternating 20 and $33^{\circ} \mathrm{C}$ (hypotheses accepted against a whole model, respectively: $P=0.2309$, Figure 4; $P=0.3961$, Figure 5; $P=0.3904$, Supplementary Figure 1). For these treatments, the three $M$. robertsii isolates had the fastest growth, with ESALQ 1426 and ESALQ 5168 being grouped with the highest rates under these three temperature conditions. Similarly, the three temperature regimes resulted in five isolates ( $M$. brunneum ESALQ 5022, ESALQ 5181 and ESALQ 5286, and M. anisopliae ESALQ 1076 and ESALQ 1604) consistently showing the lowest growth rates (Figures 4-5, Supplementary Figure 1).

In summary, the three $M$. robertsii isolates achieved higher growth at $33^{\circ} \mathrm{C}$, while isolates of $M$. brunneum and $M$. anisopliae had optimal growth rates at $25^{\circ} \mathrm{C}$. For all 12 isolates, mycelial growth was slower at $15^{\circ} \mathrm{C}$. A comparison of growth rates for each isolate is shown in Supplementary Figure 2.

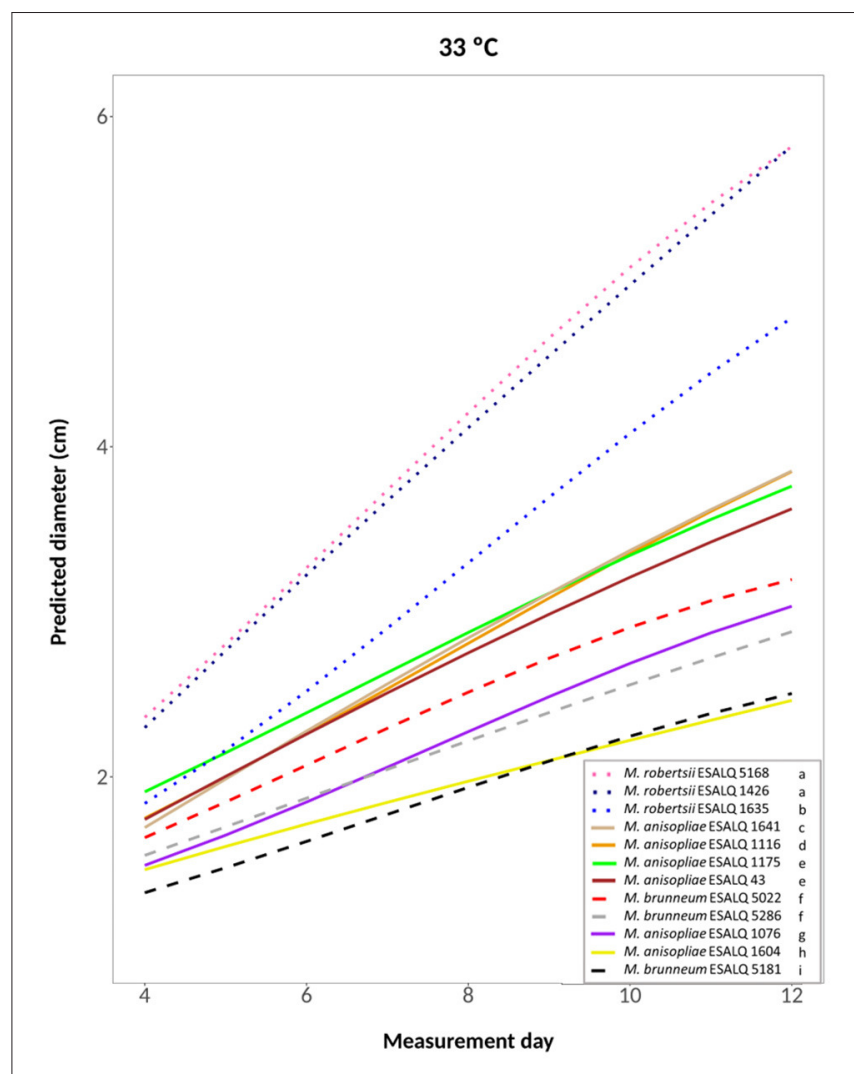

FIGURE 5 | Predicted diameter of colonies of isolates of Metarhizium robertsii, M. brunneum, and $M$. anisopliae s.str. Mani 2 after 12 days at $33^{\circ} \mathrm{C}$ constant, adopting a cubic model ( $\alpha=0.05 \%)$.

\section{Temperature Affecting the Survival of Conidia}

The beta-binomial model, with the parameters of the distribution location (mean) and scale (variance), brought a plausible realization of the data of temperature effects on conidial survival (Table 2). All 12 isolates maintained high viabilities at 20 and $25^{\circ} \mathrm{C}$, but the same did not occur at $40^{\circ} \mathrm{C}$ : conidia of all $M$. brunneum and $M$. robertsii isolates exhibited very low proportions of survival, while the conidia of the $M$. anisopliae isolates showed higher tolerance.

A likelihood-ratio test was conducted for each temperature to check for similarities between isolates and according to the experimental design. The isolates were separated into two groups for the treatments at $20^{\circ} \mathrm{C}$ (hypothesis accepted, $P=0.4628$ ): one composed of the isolate $M$. robertsii ESALQ 5168, with a slightly lower predicted proportion of germination than the other 11 isolates. At $25^{\circ} \mathrm{C}$, no differences were found among the 12 isolates (hypothesis accepted, $P=0.6220$ ). At $40^{\circ} \mathrm{C}$, it was possible to separate the isolates into four groups (hypothesis accepted, $P$ $=0.0652$ ) (in order of high to low tolerance): (i) $M$. anisopliae ESALQ 1175 and ESALQ 1641; (ii) M. anisopliae ESALQ 1076, ESALQ 43, and ESALQ 1116; (iii) M. anisopliae ESALQ 1604, $M$. robertsii ESALQ 1635, M. brunneum ESALQ 5286, and ESALQ 
TABLE 2 | Survival of conidia (percentage) of Metarhizium robertsii (Mr), M. brunneum (Mb), and M. anisopliae s.str.

\begin{tabular}{|c|c|c|c|c|c|c|c|c|c|c|c|}
\hline \multicolumn{4}{|c|}{ Conidial survival at $20^{\circ} \mathrm{C}$} & \multicolumn{4}{|c|}{ Conidial survival at $25^{\circ} \mathrm{C}$} & \multicolumn{4}{|c|}{ Conidial survival at $40^{\circ} \mathrm{C}$} \\
\hline \multicolumn{2}{|c|}{ Species/Isolate } & \multicolumn{2}{|c|}{$\%$} & \multicolumn{2}{|c|}{ Species/Isolate } & \multicolumn{2}{|c|}{$\%$} & \multicolumn{2}{|c|}{ Species/Isolate } & \multicolumn{2}{|c|}{$\%$} \\
\hline$M b$ & ESALQ 5286 & 94.5 & a & Ma & ESALQ 43 & 94.3 & a & Ma & ESALQ 1175 & 66.6 & a \\
\hline Ma & ESALQ 43 & 94.1 & a & $M b$ & ESALQ 5286 & 93.7 & $a$ & Ma & ESALQ 1641 & 61.1 & a \\
\hline Ma & ESALQ 1604 & 93.5 & a & $M b$ & ESALQ 5022 & 92.7 & $a$ & Ma & ESALQ 1076 & 44.1 & $b$ \\
\hline$M b$ & ESALQ 5181 & 93.4 & a & $M b$ & ESALQ 5181 & 90.7 & a & Ma & ESALQ 43 & 34.4 & $\mathrm{~b}$ \\
\hline Ma & ESALQ 1076 & 91.7 & a & Ma & ESALQ 1175 & 89.6 & a & Ma & ESALQ 1116 & 26.6 & $b$ \\
\hline$M r$ & ESALQ 1426 & 91.3 & $a$ & Ma & ESALQ 1116 & 89.5 & $a$ & Ma & ESALQ 1604 & 8.9 & $\mathrm{C}$ \\
\hline Ma & ESALQ 1641 & 91.3 & $a$ & $M r$ & ESALQ 1426 & 89.2 & $a$ & $M r$ & ESALQ 1635 & 5.1 & C \\
\hline$M b$ & ESALQ 5022 & 90.8 & a & Ma & ESALQ 1604 & 89.1 & a & $M b$ & ESALQ 5286 & 4.7 & C \\
\hline Ma & ESALQ 1175 & 90.6 & $a$ & $M r$ & ESALQ 1635 & 89.0 & $a$ & $M b$ & ESALQ 5022 & 3.8 & C \\
\hline$M r$ & ESALQ 1635 & 90.4 & $a$ & Ma & ESALQ 1076 & 89.0 & $a$ & $M r$ & ESALQ 5168 & 1.8 & d \\
\hline Ma & ESALQ 1116 & 89.8 & $a$ & $M r$ & ESALQ 5168 & 86.9 & $a$ & $M r$ & ESALQ 1426 & 1.7 & d \\
\hline$M r$ & ESALQ 5168 & 84.5 & $b$ & Ma & ESALQ 1641 & 86.4 & $\mathrm{a}$ & $M b$ & ESALQ 5181 & 0.5 & $d$ \\
\hline
\end{tabular}

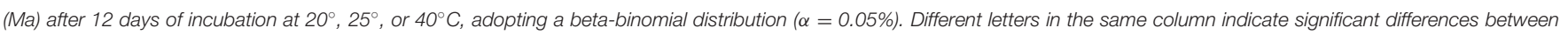
isolates for each temperature.

5022; and (iv) M. robertsii ESALQ 5168 and ESALQ 1426, M. brunneum ESALQ 5181.

In order to give an overview of all results, Table 3 contains a summary of the performance of each of the 12 isolates across all the parameters tested and shows that isolates of the same species can exhibit very different responses depending on environmental variables.

\section{DISCUSSION}

Solar radiation, especially of the UV-B type, is very harmful to fungal propagules, significantly affecting their survival and efficacy against insects in the environment (Ignoffo and Garcia, 1992; Inglis et al., 2001; Fernandes et al., 2015; Acheampong et al., 2020b). Previous reports (e.g., Braga et al., 2001a,c; Fernández-Bravo et al., 2017) showed that 2 h of exposure to UVB light (irradiances of 920 or $1,200 \mathrm{~mW} \mathrm{~m}^{-2}$, corresponding to total doses of 6.6 or $8.6 \mathrm{~kJ} \mathrm{~m}^{-2}$, respectively) was enough to substantially reduce conidial culturability (in some cases, more than 50\%) of Metarhizium spp. isolates, including some of Brazilian origin. In the present study, it was only after $6 \mathrm{~h}$ of exposure (total dose of $14.28 \mathrm{~kJ} \mathrm{~m}^{-2}$ ) that the germination rates were reduced for almost all 12 isolates of Metarhizium spp. from Brazil, with five of them becoming completely inactivated after $8 \mathrm{~h}$ of exposure (total dose of $19.04 \mathrm{~kJ} \mathrm{~m}^{-2}$ ).

Considerable intra- and inter-specific variability in UV-B tolerance was found among the 12 isolates. Similar observations were reported by Fargues et al. (1996), who compared the survival of conidia of isolates of Metarhizium flavoviride, Beauveria bassiana, M. anisopliae s.l., and Cordyceps fumosorosea (= Isaria fumosorosea, Paecilomyces fumosoroseus) and found different degrees of tolerance between and within species (e.g., for $B$. bassiana isolates, survival ranged from 0 to 100\%). Furthermore, Fernandes et al. (2007) found a large range of resilience to UV$B$ radiation testing 59 Beauveria spp. isolates, while Huang and Feng (2009) reported variable tolerances among 20 B. bassiana isolates, based on UV-B lethal doses $\left(\mathrm{LD}_{50}, \mathrm{LD}_{75}\right.$, and $\mathrm{LD}_{95}$; J $\mathrm{cm}^{-2}$ ) after irradiation.

When investigating the association between the latitude of origin of Beauveria spp. isolates (most of them from Brazil) and their UV tolerance, Fernandes et al. (2007) reported a significant inverse correlation, i.e., the most UV tolerant isolates were from regions of lower latitude, where solar irradiation is more intense than at higher latitudes. Braga et al. (2001c), working with isolates of $M$. anisopliae s.l., reported a similar correlation and stated that natural selection for UV-B tolerance must have occurred with these isolates. In the present study, no apparent latitudinal gradient in UV-B tolerance could be seen, as the isolate most susceptible to UV-B radiation (ESALQ 1641) was obtained in a region of lower latitude, while the second (ESALQ 1076) and third (ESALQ 1116) most tolerant isolates were collected in areas of higher latitudes. Likewise, Fargues et al. (1996) did not find a correlation between the geographic origin of $B$. bassiana isolates and UV-B tolerance.

Our results also indicate no apparent relationship between UV-B tolerance and the substrate of isolation or fungal species. Isolates obtained from different substrates (i.e., insect, soil or root) or of varying Metarhizium species were grouped by the similarity of their survival curves (Figure 1), while others originating from the same type of substrate had different angles, even if they were of the same species (e.g., M. anisopliae ESALQ 1076 and ESALQ 1175, both from meadow soil). This finding is in accordance with reports that used Metarhizium spp. and Beauveria spp., and a positive correlation involving UV$B$ tolerance and isolation substrate or fungal species has yet to be found (Fernandes et al., 2007; Fernández-Bravo et al., 2016, 2017).

One $M$. robertsii isolate (ESALQ 1635) was by far the most UV-B tolerant, and some isolates of the three species had similar conidial survival curves. This indicates that tolerance to UV$\mathrm{B}$ radiation was not selected at the species level among those considered adapted for the above-ground environment. Evidence 


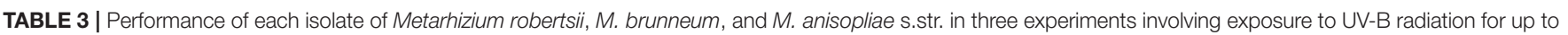

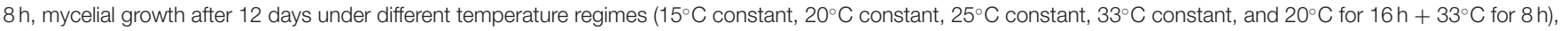
and conidial survival after 12 days at three temperatures $\left(20^{\circ}, 25^{\circ}\right.$, and $\left.40^{\circ} \mathrm{C}\right)$.

\begin{tabular}{|c|c|c|c|c|c|c|c|c|}
\hline $\begin{array}{l}\text { UV-B } \\
\text { tolerance }\end{array}$ & $\begin{array}{l}\text { Mycelial } \\
\text { Growth } \\
15^{\circ} \mathrm{C} \text { constant }\end{array}$ & $\begin{array}{l}\text { Mycelial } \\
\text { Growth } \\
20^{\circ} \mathrm{C} \text { constant }\end{array}$ & $\begin{array}{l}\text { Mycelial } \\
\text { Growth } \\
25^{\circ} \mathrm{C} \text { constant }\end{array}$ & $\begin{array}{l}\text { Mycelial } \\
\text { Growth } \\
33^{\circ} \mathrm{C} \text { constant }\end{array}$ & $\begin{array}{l}\text { Mycelial } \\
\text { Growth } \\
20^{\circ} \mathrm{C} / 16 \mathrm{~h}+33^{\circ} \mathrm{C} / 8 \mathrm{~h}\end{array}$ & $\begin{array}{l}\text { Conidial } \\
\text { Survival } \\
20^{\circ} \mathrm{C}\end{array}$ & $\begin{array}{l}\text { Conidial } \\
\text { Survival } \\
25^{\circ} \mathrm{C}\end{array}$ & $\begin{array}{l}\text { Conidial } \\
\text { Survival } \\
40^{\circ} \mathrm{C}\end{array}$ \\
\hline $\begin{array}{l}\text { ESALQ } \\
1635\end{array}$ & $\begin{array}{l}\text { ESALQ } \\
5181\end{array}$ & $\begin{array}{l}\text { ESALQ } \\
1426\end{array}$ & $\begin{array}{l}\text { ESALQ } \\
5168\end{array}$ & $\begin{array}{l}\text { ESALQ } \\
5168\end{array}$ & $\begin{array}{l}\text { ESALQ } \\
5168\end{array}$ & $\begin{array}{l}\text { ESALQ } \\
5286\end{array}$ & $\begin{array}{l}\text { ESALQ } \\
43\end{array}$ & $\begin{array}{l}\text { ESALQ } \\
1175\end{array}$ \\
\hline $\begin{array}{l}\text { ESALQ } \\
1076\end{array}$ & $\begin{array}{l}\text { ESALQ } \\
1426\end{array}$ & $\begin{array}{l}\text { ESALQ } \\
5168\end{array}$ & $\begin{array}{l}\text { ESALQ } \\
1426\end{array}$ & $\begin{array}{l}\text { ESALQ } \\
1426\end{array}$ & $\begin{array}{l}\text { ESALQ } \\
1426\end{array}$ & $\begin{array}{l}\text { ESALQ } \\
43\end{array}$ & $\begin{array}{l}\text { ESALQ } \\
5286\end{array}$ & $\begin{array}{l}\text { ESALQ } \\
1641\end{array}$ \\
\hline $\begin{array}{l}\text { ESALQ } \\
1116\end{array}$ & \begin{tabular}{|l} 
ESALQ \\
5022
\end{tabular} & $\begin{array}{l}\text { ESALQ } \\
1641\end{array}$ & $\begin{array}{l}\text { ESALQ } \\
1635\end{array}$ & \begin{tabular}{|l} 
ESALQ \\
1635
\end{tabular} & \begin{tabular}{|l} 
ESALQ \\
1635
\end{tabular} & $\begin{array}{l}\text { ESALQ } \\
1604\end{array}$ & $\begin{array}{l}\text { ESALQ } \\
5022\end{array}$ & \begin{tabular}{|l} 
ESALQ \\
1076
\end{tabular} \\
\hline $\begin{array}{l}\text { ESALQ } \\
1604\end{array}$ & $\begin{array}{l}\text { ESALQ } \\
5168\end{array}$ & $\begin{array}{l}\text { ESALQ } \\
5286\end{array}$ & \begin{tabular}{|l} 
ESALQ \\
1641 \\
\end{tabular} & $\begin{array}{l}\text { ESALQ } \\
1641\end{array}$ & $\begin{array}{l}\text { ESALQ } \\
1175\end{array}$ & $\begin{array}{l}\text { ESALQ } \\
5181\end{array}$ & $\begin{array}{l}\text { ESALQ } \\
5181\end{array}$ & $\begin{array}{l}\text { ESALQ } \\
43\end{array}$ \\
\hline $\begin{array}{l}\text { ESALQ } \\
5022\end{array}$ & \begin{tabular}{|l} 
ESALQ \\
1635 \\
\end{tabular} & $\begin{array}{l}\text { ESALQ } \\
1604\end{array}$ & \begin{tabular}{|l} 
ESALQ \\
1116
\end{tabular} & $\begin{array}{l}\text { ESALQ } \\
1116 \\
\end{array}$ & $\begin{array}{l}\text { ESALQ } \\
1641\end{array}$ & $\begin{array}{l}\text { ESALQ } \\
1076\end{array}$ & $\begin{array}{l}\text { ESALQ } \\
1175\end{array}$ & $\begin{array}{l}\text { ESALQ } \\
1116\end{array}$ \\
\hline $\begin{array}{l}\text { ESALQ } \\
5168\end{array}$ & $\begin{array}{l}\text { ESALQ } \\
1604\end{array}$ & $\begin{array}{l}\text { ESALQ } \\
43\end{array}$ & $\begin{array}{l}\text { ESALQ } \\
1175\end{array}$ & $\begin{array}{l}\text { ESALQ } \\
1175\end{array}$ & $\begin{array}{l}\text { ESALQ } \\
1116\end{array}$ & $\begin{array}{l}\text { ESALQ } \\
1426\end{array}$ & $\begin{array}{l}\text { ESALQ } \\
1116\end{array}$ & \begin{tabular}{|l} 
ESALQ \\
1604
\end{tabular} \\
\hline $\begin{array}{l}\text { ESALQ } \\
1426\end{array}$ & \begin{tabular}{|l} 
ESALQ \\
5286
\end{tabular} & $\begin{array}{l}\text { ESALQ } \\
1116\end{array}$ & $\begin{array}{l}\text { ESALQ } \\
43\end{array}$ & $\begin{array}{l}\text { ESALQ } \\
43\end{array}$ & \begin{tabular}{|l} 
ESALQ \\
43
\end{tabular} & $\begin{array}{l}\text { ESALQ } \\
1641\end{array}$ & $\begin{array}{l}\text { ESALQ } \\
1426\end{array}$ & $\begin{array}{l}\text { ESALQ } \\
1635\end{array}$ \\
\hline $\begin{array}{l}\text { ESALQ } \\
1175\end{array}$ & $\begin{array}{l}\text { ESALQ } \\
43\end{array}$ & \begin{tabular}{|l} 
ESALQ \\
1175 \\
\end{tabular} & $\begin{array}{l}\text { ESALQ } \\
1604\end{array}$ & $\begin{array}{l}\text { ESALQ } \\
5022\end{array}$ & $\begin{array}{l}\text { ESALQ } \\
5022\end{array}$ & $\begin{array}{l}\text { ESALQ } \\
5022\end{array}$ & $\begin{array}{l}\text { ESALQ } \\
1604\end{array}$ & $\begin{array}{l}\text { ESALQ } \\
5286\end{array}$ \\
\hline $\begin{array}{l}\text { ESALQ } \\
43\end{array}$ & $\begin{array}{l}\text { ESALQ } \\
1641\end{array}$ & \begin{tabular}{|l} 
ESALQ \\
5022
\end{tabular} & $\begin{array}{l}\text { ESALQ } \\
5286\end{array}$ & $\begin{array}{l}\text { ESALQ } \\
5286\end{array}$ & $\begin{array}{l}\text { ESALQ } \\
5286\end{array}$ & $\begin{array}{l}\text { ESALQ } \\
1175\end{array}$ & $\begin{array}{l}\text { ESALQ } \\
1635\end{array}$ & $\begin{array}{l}\text { ESALQ } \\
5022\end{array}$ \\
\hline \begin{tabular}{|l} 
ESALQ \\
5181
\end{tabular} & $\begin{array}{l}\text { ESALQ } \\
1116\end{array}$ & \begin{tabular}{|l} 
ESALQ \\
1635
\end{tabular} & $\begin{array}{l}\text { ESALQ } \\
5022\end{array}$ & $\begin{array}{l}\text { ESALQ } \\
1076\end{array}$ & $\begin{array}{l}\text { ESALQ } \\
1076\end{array}$ & $\begin{array}{l}\text { ESALQ } \\
1635\end{array}$ & $\begin{array}{l}\text { ESALQ } \\
1076\end{array}$ & $\begin{array}{l}\text { ESALQ } \\
5168\end{array}$ \\
\hline $\begin{array}{l}\text { ESALQ } \\
5286\end{array}$ & \begin{tabular}{|l} 
ESALQ \\
1175 \\
\end{tabular} & $\begin{array}{l}\text { ESALQ } \\
1076 \\
\end{array}$ & $\begin{array}{l}\text { ESALQ } \\
1076\end{array}$ & $\begin{array}{l}\text { ESALQ } \\
1604\end{array}$ & $\begin{array}{l}\text { ESALQ } \\
1604\end{array}$ & $\begin{array}{l}\text { ESALQ } \\
1116\end{array}$ & $\begin{array}{l}\text { ESALQ } \\
5168\end{array}$ & $\begin{array}{l}\text { ESALQ } \\
1426\end{array}$ \\
\hline $\begin{array}{l}\text { ESALQ } \\
1641\end{array}$ & $\begin{array}{l}\text { ESALQ } \\
1076\end{array}$ & \begin{tabular}{|l} 
ESALQ \\
5181
\end{tabular} & $\begin{array}{l}\text { ESALQ } \\
5181\end{array}$ & $\begin{array}{l}\text { ESALQ } \\
5181\end{array}$ & $\begin{array}{l}\text { ESALQ } \\
5181\end{array}$ & $\begin{array}{l}\text { ESALQ } \\
5168\end{array}$ & $\begin{array}{l}\text { ESALQ } \\
1641\end{array}$ & $\begin{array}{l}\text { ESALQ } \\
5181\end{array}$ \\
\hline
\end{tabular}

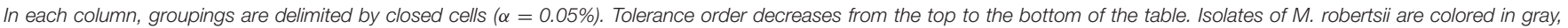
M. brunneum in blue and M. anisopliae in green.

suggests that a difference in habitat (e.g., phylloplane vs. soil) does not influence the ability of isolates to resist elevated levels of UV radiation (Fernández-Bravo et al., 2016, 2017).

Many reports about the effects of temperature on Metarhizium spp. isolates state that the optimal temperature for growth ranges between 25 and $30^{\circ} \mathrm{C}$ (Ekesi et al., 1999; Dimbi et al., 2004; Zimmermann, 2007; Acheampong et al., 2020a). Our data for $M$. anisopliae and M. brunneum isolates corroborate this and show that the best temperature for their mycelial growth in vitro was $25^{\circ} \mathrm{C}$. At temperatures higher than $30^{\circ} \mathrm{C}$, isolates can grow, but there is a decrease in growth rate, and generally, growth ceases at $35^{\circ} \mathrm{C}$ (Ouedraogo et al., 1997; Acheampong et al., 2020a). These authors reported an isolate of $M$. anisopliae s.l. with an optimum growth temperature of $28-32^{\circ} \mathrm{C}$. Welling et al. (1994) studied an isolate of $M$. flavoviride that achieved the highest growth at 30$34^{\circ} \mathrm{C}$. Similarly, our three $M$. robertsii isolates had the highest growth rates at $33^{\circ} \mathrm{C}$, indicating higher thermotolerance of the mycelium than for the M. anisopliae and M. brunneum isolates.

Overall, the three isolates of $M$. robertsii showed relatively high growth rates, the three isolates of $M$. brunneum had the lowest growth rates, and the six M. anisopliae isolates were intermediate. However, considerable intraspecific variability was found for the isolates of all three species. Ouedraogo et al. (1997) also reported within-species variability between isolates of $M$. anisopliae s.l. and M. flavoviride.
An association between thermotolerance and habitat of origin was reported for species such as $M$. anisopliae s.l., $M$. flavoviride, and $M$. rileyi (= Nomuraea rileyi), with isolates from tropical or subtropical regions being more tolerant and having higher growth rates at higher temperatures than isolates from temperate areas (Fargues et al., 1992; Vidal et al., 1997). The performance of the three M. brunneum isolates under different temperatures in this study, the high prevalence of this species in temperate zones such as North America and Europe (where temperatures are cooler), and their low occurrence in South America (Steinwender et al., 2014; Rezende et al., 2015) might indicate that this species is not adapted to tolerate high temperatures. Our isolates were obtained from tropical and subtropical regions in Brazil, and an association between thermotolerance and latitude of origin could not be found in our study (e.g., M. robertsii ESALQ 1426, from south Brazil, was more tolerant to $33^{\circ} \mathrm{C}$ than isolates from northeast Brazil). Other studies also reported the absence of a relationship between thermotolerance and isolate geographic origin (Metarhizium spp. and B. bassiana) (De Croos and Bidochka, 1999; Devi et al., 2005; Rangel et al., 2005). Furthermore, no association was found between tolerance and substrate of isolation (e.g., M. robertsii ESALQ 1426, from soil, and $M$. robertsii ESALQ 5168, from insects, had the highest growth rates and grouped at all temperatures except at $\left.15^{\circ} \mathrm{C}\right)$. 
Exposure time to certain temperatures is essential when considering the tolerance of an isolate. Welling et al. (1994) reported that two out of three Metarhizium spp. isolates showed higher growth in a temperature cycle of $16 \mathrm{~h} / 25^{\circ} \mathrm{C}+8 \mathrm{~h} / 34^{\circ} \mathrm{C}$ compared to $34^{\circ} \mathrm{C}$ constant, and all of them were able to grow at temperatures above $40^{\circ} \mathrm{C}$ when the temperature cycle included a period of $16 \mathrm{~h}$ at $25^{\circ} \mathrm{C}$, although with a decrease in growth rate compared to treatments with lower maximal temperatures (e.g., $25^{\circ} \mathrm{C}$ constant or cycle of $16 \mathrm{~h} / 25^{\circ} \mathrm{C}+8 \mathrm{~h} / 30^{\circ} \mathrm{C}$ ). In our study, we used a cycle of $8 \mathrm{~h}$ at $33^{\circ} \mathrm{C}$ and $16 \mathrm{~h}$ at $20^{\circ} \mathrm{C}$, and even though the three isolates of M. brunneum and two of the $M$. anisopliae isolates did not grow well at $33^{\circ} \mathrm{C}$ constant, growth was numerically higher than with alternating temperatures.

The viabilities of dried conidia were not significantly affected by treatments at 20 or $25^{\circ} \mathrm{C}$, varying in germination rates between 84 and $95 \%$ after 12 days, with only a slight reduction. On the other hand, there was an apparent effect of high temperature, as dried conidia of all 12 isolates showed a significant decrease in survival at $40^{\circ} \mathrm{C}$. This lower viability can be explained by the fact that high temperatures can retard and inhibit conidial germination and cause growth termination (Walstad et al., 1970; Inglis et al., 2001). Conidia of two isolates of M. anisopliae s.l. submitted to a range of temperatures $\left(-20\right.$ to $\left.37^{\circ} \mathrm{C}\right)$ survived for longer periods in the lower range (Daoust and Roberts, 1983), and dried conidia of an isolate of M. acridum (reported as $M$. flavoviride by the authors) also had a higher germination percentage after being stored in colder conditions compared to storage at higher temperatures (Moore et al., 1996). Clerk and Madelin (1965) evaluated the conidial survival of an isolate of $M$. anisopliae s.l. at 8,18 , and $25^{\circ} \mathrm{C}$ under different $\mathrm{RH}$ conditions, and treatments at $25^{\circ} \mathrm{C}$ affected conidia the most. A reduction in the temperature of storage can increase the survival of conidia (Clerk and Madelin, 1965; Walstad et al., 1970).

In agreement with other studies (Fargues et al., 1997; Rangel et al., 2005), and similar to what we found about UV-B radiation, there was no apparent correlation observed between conidial thermotolerance and latitude or substrate of isolation. Our hypothesis relating this tolerance to fungal species was not fully met since ESALQ 1604 (M. anisopliae) exhibited similar conidial survival to ESALQ 1635 (M. robertsii), and ESALQ 5022 and ESALQ 5181 (M. brunneum). However, it is worth noting that the other five M. anisopliae isolates had significantly higher conidial survival proportions at $40^{\circ} \mathrm{C}$. Rangel et al. (2005) found some variability in wet and dry heat tolerance of conidia among isolates of Metarhizium species exposed to 40 and $45^{\circ} \mathrm{C}$, with M. acridum isolates exhibiting a significantly higher tolerance compared to isolates of M. anisopliae s.l., M. robertsii, or M. brunneum.

Although our experimental time was relatively short, it was enough to reduce conidial viabilities of some isolates below $5 \%$, evidencing their susceptibility to high temperatures, an undesirable characteristic for biological control purposes in field conditions, especially in tropical countries (such as Brazil) where the air temperatures can reach above $40^{\circ} \mathrm{C}$ in the summer. Conidial survival at such high temperatures can be increased by drying and developing formulations with oils (Moore et al., 1996; Paixão et al., 2017).

Mycelia comprises a mass of hyphae related to the absorption of nutrients, vegetative growth, and plant associations. In contrast, conidia are asexual, infective spores capable of persisting in the environment in the absence of a host, forming reservoirs of inoculum (Evans and Hywel-Jones, 1997; Hesketh et al., 2010; Behie et al., 2012; Vega et al., 2012). Because of this, conidia are more subjected to adverse environmental conditions than mycelia; thus, they should exhibit increased tolerance to abiotic factors to improve their survival. Our data showed that mycelial growth rates of the three isolates of $M$. robertsii were higher at the highest temperature tested, but their conidia did not tolerate high temperature or UV-B radiation. On the other hand, the opposite result was obtained for most isolates of $M$. anisopliae, which produced conidia that showed increased tolerance to the stressful conditions tested, but the same could not be concluded for their mycelial growth in vitro. The fact that mycelia of $M$. robertsii isolates had optimum growth at $33^{\circ} \mathrm{C}$, while their conidia were not tolerant to storage at $40^{\circ} \mathrm{C}$ (all three isolates) or UV-B radiation (ESALQ 1426 and ESALQ 5168), indicates a stronger selection pressure for mycelial growth rather than survival of conidia. This trait may have an essential role in their association with plant roots, where the active hyphae are the structure forming the association in the rhizosphere (Sasan and Bidochka, 2012; Behie and Bidochka, 2014). In contrast, conidia of $M$. anisopliae isolates could better tolerate the adverse experimental conditions, suggesting that adaptation for unfavorable conditions of these propagules is selected for, as they are important for survival in the environment and for infecting new hosts.

Although we found some variation in tolerance to UV-B radiation and high temperatures between isolates of the same species, similarities could also be seen, e.g., the three isolates of $M$. robertsii growing faster at $33^{\circ} \mathrm{C}$ or conidia of isolates of M. anisopliae better tolerating incubation at $40^{\circ} \mathrm{C}$. The present study shows that isolates of each species represent biological plasticity and that isolates of the same species can exhibit very different responses to environmental variables, thus not making it possible to generalize results to the species level. A similar conclusion was reported by Canassa et al. (2020) concerning the ability of Metarhizium spp. isolates to interact with plants. Our study provides new insights into the ecology of entomopathogenic fungi and their adaptations for variation of important environmental abiotic factors that can impact the fungi abundance and distribution patterns. Knowledge of such adaptations can provide the foundation for future selection of candidate isolates with high environmental resilience for the development of biological control agents.

\section{DATA AVAILABILITY STATEMENT}

The datasets presented in this study can be found in online repositories. The names of the repository/repositories and accession number(s) can be found below: Repository Open Science Framework (OSF) doi: 10.17605/OSF.IO/EJXY3.

\section{AUTHOR CONTRIBUTIONS}

JC, NM, and íD: conceptualization. JC, NM, and íD: methodology. MF and CD: formal analysis. JC: investigation. 
JC: data curation. JC: writing-original draft preparation. JC, $\mathrm{MF}, \mathrm{CD}, \mathrm{NM}$, and íD: writing-review and editing. NM and íD: supervision. All authors have read and agreed to the published version of the manuscript.

\section{FUNDING}

This research was funded by the São Paulo Research Foundation (FAPESP), Grant No. 2017/20491-0.

\section{REFERENCES}

Acheampong, M. A., Coombes, C. A., Moore, S. D., and Hill, M. P. (2020a). Temperature tolerance and humidity requirements of select entomopathogenic fungal isolates for future use in citrus IPM programmes. J. Invertebr. Pathol. 174:107436. doi: 10.1016/j.jip.2020.107436

Acheampong, M. A., Hill, M. P., Moore, S. D., and Coombes, C. A. (2020b). UV sensitivity of Beauveria bassiana and Metarhizium anisopliae isolates under investigation as potential biological control agents in South African citrus orchards. Fungal Biol. 124, 304-310. doi: 10.1016/j.funbio.2019.08.009

Barelli, L., Moonjely, S., Behie, S. W., and Bidochka, M. J. (2016). Fungi with multifunctional lifestyles: endophytic insect pathogenic fungi. Plant Mol. Biol. 90, 657-664. doi: 10.1007/s11103-015-0413-z

Behie, S. W., and Bidochka, M. J. (2014). Ubiquity of insect-derived nitrogen transfer to plants by endophytic insect-pathogenic fungi: An additional branch of the soil nitrogen cycle. Appl. Environ. Microbiol. 80, 1553-1560. doi: 10.1128/AEM.03338-13

Behie, S. W., Moreira, C. C., Sementchoukova, I., Barelli, L., Zelisko, P. M., and Bidochka, M. J. (2017). Carbon translocation from a plant to an insect-pathogenic endophytic fungus. Nat. Commun. 8:14245. doi: $10.1038 /$ ncomms 14245

Behie, S. W., Zelisko, P. M., and Bidochka, M. J. (2012). Endophytic insectparasitic fungi translocate nitrogen directly from insects to plants. Science 336, 1576-1577. doi: 10.1126/science.1222289

Bidochka, M. J., Kamp, A. M., Lavender, T. M., Dekoning, J., and De Croos, J. N. A. (2001). Habitat association in two genetic groups of the insect-pathogenic fungus Metarhizium anisopliae: uncovering cryptic species? Appl. Environ. Microbiol. 67, 1335-1342. doi: 10.1128/AEM.67.3.1335-1342.2001

Botelho, A. B. R. Z., Alves-Pereira, A., Prado, R. C., Zucchi, M. I., and Delalibera Júnior, I. (2019). Metarhizium species in soil from Brazilian biomes: a study of diversity, distribution, and association with natural and agricultural environments. Fungal Ecol. 41:289-300. doi: 10.1016/j.funeco.2019.07.004

Braga, G. U. L., Flint, S. D., Messias, C. L., Anderson, A. J., and Roberts, D. W. (2001a). Effect of UV-B on conidia and germlings of the entomopathogenic hyphomycete Metarhizium anisopliae. Mycol. Res. 105:874-882. doi: 10.1017/S0953756201004270

Braga, G. U. L., Flint, S. D., Miller, C. D., Anderson, A. J., and Roberts, D. W. (2001b). Both solar UVA and UVB radiation impair conidial culturability and delay germination in the entomopathogenic fungus Metarhizium anisopliae. Photochem. Photobiol. 74, 734-739. doi: 10.1562/0031-8655(2001)074\&lt;0734:BSUAUR\&gt;2.0.CO;2

Braga, G. U. L., Flint, S. D., Miller, C. D., Anderson, A. J., and Roberts, D. W. (2001c). Variability in response to UV-B among species and strains of Metarhizium isolated from sites at latitudes from $61^{\circ} \mathrm{N}$ to $54^{\circ} \mathrm{S}$. J. Invertebr. Pathol. 78, 98-108. doi: 10.1006/jipa.2001.5048

Bruck, D. J. (2005). Ecology of Metarhizium anisopliae in soilless potting media and the rhizosphere: implications for pest management. Biol. Control 32, 155-163. doi: 10.1016/j.biocontrol.2004.09.003

Brunner-Mendoza, C., Reyes-Montes, M. R., Moonjely, S., Bidochka, M. J., and Toriello, C. (2019). A review on the genus Metarhizium as an entomopathogenic microbial biocontrol agent with emphasis on its use and utility in Mexico. Biocontrol Sci. Technol. 29, 83-102. doi: 10.1080/09583157.2018.1531111

\section{ACKNOWLEDGMENTS}

CD acknowledges the Brazilian National Council for Scientific and Technological Development (CNPq) for her fellowship.

\section{SUPPLEMENTARY MATERIAL}

The Supplementary Material for this article can be found online at: https://www.frontiersin.org/articles/10.3389/ffunb. 2021.645737/full\#supplementary-material

Canassa, F., D’Alessandro, C. P., Sousa, S. B., Demétrio, C. G. B., Meyling, N. V., Klingen, I., et al. (2020). Fungal isolate and crop cultivar influence the beneficial effects of root inoculation with entomopathogenic fungi in strawberry. Pest Manag. Sci. 76, 1472-1482. doi: 10.1002/ps.5662

Clerk, G. C., and Madelin, M. F. (1965). The longevity of conidia of three insect-parasitizing hyphomycetes. Trans. Br. Mycol. Soc. 48, 193-209. doi: 10.1016/S0007-1536(65)80086-9

Daoust, R. A., and Roberts, D. W. (1983). Studies on the prolonged storage of Metarhizium anisopliae conidia: effect of temperature and relative humidity on conidial viability and virulence against mosquitoes. J. Invertebr. Pathol. 41, 143-150. doi: 10.1016/0022-2011(83)90213-6

De Croos, J. N. A., and Bidochka, M. J. (1999). Effects of low temperature on growth parameters in the entomopathogenic fungus Metarhizium anisopliae. Can. J. Microbiol. 45, 1055-1061. doi: 10.1139/w99-098

Demétrio, C. G. B., Hinde, J., and Moral, R. A. (2014). Models for overdispersed data in Entomology. In: Ecological Modelling Applied to Entomology, eds C. Ferreira, W. Godoy (Cham: Springer), 219-259. doi: 10.1007/978-3-319-06877-0_9

Devi, K. U., Sridevi, V., Mohan, C. M., and Padmavathi, J. (2005). Effect of high temperature and water stress on in vitro germination and growth in isolates of the entomopathogenic fungus Beauveria bassiana (Bals.) Vuillemin. J. Invertebr. Pathol. 88, 181-189. doi: 10.1016/j.jip.2005.02.001

Dimbi, S., Maniania, N. K., Lux, S. A., and Mueke, J. M. (2004). Effect of constant temperatures on germination, radial growth and virulence of Metarhizium anisopliae to three species of African tephritid fruit flies. BioControl 49, 83-94. doi: 10.1023/B:BICO.0000009397.84153.79

Ekesi, S., Maniania, N. K., and Ampong-Nyarko, K. (1999). Effect of temperature on germination, radial growth and virulence of Metarhizium anisopliae and Beauveria bassiana on Megalurothrips sjostedti. Biocontrol Sci. Technol. 9, 177-185. doi: 10.1080/09583159929767

Evans, H. C., and Hywel-Jones, N. L. (1997). "Entomopathogenic fungi," in World Crop Pests Vol. 7, eds Y. Ben-Dov and C. J. Hodgson (Amsterdam: Elsevier), 3-27. doi: 10.1016/S1572-4379(97)80075-9

Fargues, J., Goettel, M. S., Smits, N., Ouedraogo, A., and Rougier, M. (1997). Effect of temperature on vegetative growth of Beauveria bassiana isolates from different origins. Mycologia 89, 383-392. doi: 10.1080/00275514.1997.120 26797

Fargues, J., Goettel, M. S., Smits, N., Ouedraogo, A., Vidal, C., Lacey, L. A., et al. (1996). Variability in susceptibility to simulated sunlight of conidia among isolates of entomopathogenic Hyphomycetes. Mycopathologia 135, 171-181. doi: 10.1007/BF00632339

Fargues, J., Maniania, N. K., Delmas, J. C., and Smits, N. (1992). Influence de la température sur la croissance in vitro d'hyphomycètes entomopathogènes. Agronomie 12, 557-564. doi: 10.1051/agro:19920708

Fatoretto, M. B., Moral, R. A., Demétrio, C. G. B., Pádua, C. S., Menarin, V., Rojas, V. M. A., et al. (2018). Overdispersed fungus germination data: statistical analysis using R. Biocontrol. Sci. Technol. 28, 1034-1053. doi: 10.1080/09583157.2018.1504888

Fernandes, É. K. K., Rangel, D. E. N., Braga, G. U. L., and Roberts, D. W. (2015). Tolerance of entomopathogenic fungi to ultraviolet radiation: a review on screening of strains and their formulation. Curr. Genet. 61, 427-440. doi: 10.1007/s00294-015-0492-z

Fernandes, É. K. K., Rangel, D. E. N., Moraes, Á. M. L., Bittencourt, V. R. E. P., and Roberts, D. W. (2007). Variability in tolerance to UV-B 
radiation among Beauveria spp. isolates. J. Invertebr. Pathol. 96, 237-243. doi: 10.1016/j.jip.2007.05.007

Fernández-Bravo, M., Flores-León, A., Calero-López, S., Gutiérrez-Sánchez, F., Valverde-García, P., and Quesada-Moraga, E. (2017). UV-B radiationrelated effects on conidial inactivation and virulence against Ceratitis capitata (Wiedemann) (Diptera; Tephritidae) of phylloplane and soil Metarhizium sp. strains. J. Invertebr. Pathol. 148, 142-151. doi: 10.1016/j.jip.2017.06.012

Fernández-Bravo, M., Garrido-Jurado, I., Valverde-García, P., Enkerli, J., and Quesada-Moraga, E. (2016). Responses to abiotic environmental stresses among phylloplane and soil isolates of Beauveria bassiana from two holm oak ecosystems. J. Invertebr. Pathol. 141, 6-17. doi: 10.1016/j.jip.2016.09.007

Hesketh, H., Roy, H. E., Eilenberg, J., Pell, J. K., and Hails, R. S. (2010). Challenges in modelling complexity of fungal entomopathogens in semi-natural populations of insects. BioControl 55, 55-73. doi: 10.1007/s10526-009-9249-2

Hu, G., and St. Leger, R. J. (2002). Field studies using a recombinant mycoinsecticide (Metarhizium anisopliae) reveal that it is rhizosphere competent. Appl. Environ. Microbiol. 68, 6383-6387. doi: 10.1128/AEM.68.12.6383-6387.2002

Huang, B.-F., and Feng, M.-G. (2009). Comparative tolerances of various Beauveria bassiana isolates to UV-B irradiation with a description of a modeling method to assess lethal dose. Mycopathologia 168, 145-152. doi: 10.1007/s11046-009-9207-7

Ignoffo, C. M., and Garcia, C. (1992). Influence of conidial color on inactivation of several entomogenous fungi (Hyphomycetes) by simulated sunlight. Environ. Entomol. 21, 913-917. doi: 10.1093/ee/21.4.913

Inglis, G. D., Goettel, M. S., Butt, T. M., and Strasser, H. (2001). "Use ofhyphomycetous fungi for managing insect pests," in Fungi as Biocontrol Agents: Progress, Problems and Potential, eds T. M. Butt, C. Jackson, and N. Magan (Wallingford, UK: CABI), 23-69. doi: 10.1079/9780851993560.0023

Iwanicki, N. S. (2015). Monitoramento de Metarhizium spp. (Hypocreales: Clavicipitaceae) por marcadores moleculares em plantios de cana-deaçúcar. [master's thesis]. [Piracicaba (SP, Brazil)]: Escola Superior de Agricultura Luiz de Queiroz, Universidade de São Paulo. Portuguese. doi: 10.11606/D.11.2016.tde-06042016-170147

Iwanicki, N. S., Pereira, A. A., Botelho, A. B. R. Z., Rezende, J. M., Moral, R. A., Zucchi, M. I., et al. (2019). Monitoring of the field application of Metarhizium anisopliae in Brazil revealed high molecular diversity of Metarhizium spp. in insects, soil and sugarcane roots. Sci. Rep. 9:4443. doi: 10.1038/s41598-019-38594-8

Jaber, L. R., and Enkerli, J. (2016a). Effect of seed treatment duration on growth and colonization of Vicia faba by endophytic Beauveria bassiana and Metarhizium brunneum. Biol. Control 103, 187-195. doi: 10.1016/j.biocontrol.2016.09.008

Jaber, L. R., and Enkerli, J. (2016b). Fungal entomopathogens as endophytes: can they promote plant growth? Biocontrol Sci. Technol. 27, 28-41. doi: 10.1080/09583157.2016.1243227

Jaronski, S. T. (2007). "Soil ecology of the entomopathogenic Ascomycetes: a critical examination of what we (think) we know," in Use of Entomopathogenic Fungi in Biological Pest Management, eds S. Ekesi and N. K. Maniania (Research Signpost, Trivandrum), 1-53.

Kepler, R. M., Ugine, T. A., Maul, J. E., Cavigelli, M. A., and Rehner, S. A. (2015). Community composition and population genetics of insect pathogenic fungi in the genus Metarhizium from soils of a long-term agricultural research system. Environ. Microbiol. 17, 2791-2804. doi: 10.1111/1462-2920.12778

Lacey, L. A., Grzywacz, D., Shapiro-Ilan, D. I., Frutos, R., Brownbridge, M., and Goettel, M. S. (2015). Insect pathogens as biological control agents: back to the future. J. Invertebr. Pathol. 132, 1-41. doi: 10.1016/j.jip.2015.07.009

Lopes, R. B., Souza, D. A., Oliveira, C. M., and Faria, M. (2013). Genetic diversity and pathogenicity of Metarhizium spp. associated with the white grub Phyllophaga capillata (Blanchard) (Coleoptera: Melolonthidae) in a soybean field. Neotrop. Entomol. 42, 436-438. doi: 10.1007/s13744-013-0146-0

Meyling, N. V., and Eilenberg, J. (2007). Ecology of the entomopathogenic fungi Beauveria bassiana and Metarhizium anisopliae in temperate agroecosystems: potential for conservation biological control. Biol. Control 43, 145-155. doi: 10.1016/j.biocontrol.2007.07.007

Meyling, N. V., Thorup-Kristensen, K., and Eilenberg, J. (2011). Below- and aboveground abundance and distribution of fungal entomopathogens in experimental conventional and organic cropping systems. Biol. Control 59, 180-186. doi: 10.1016/j.biocontrol.2011.07.017
Molenberghs, G., Verbeke, G., and Demétrio, C. G. B. (2017). Hierarchical models with normal and conjugate random effects: a review. SORT - Stat. Oper. Res. Trans. 41, 191-254. doi: 10.2436/20.8080.02.58

Moore, D., Douro-Kpindou, O. K., Jenkins, N. E., and Lomer, C. J. (1996). Effects of moisture content and temperature on storage of Metarhizium flavoviride conidia. Biocontrol Sci. Technol. 6, 51-62. doi: 10.1080/09583159650039520

Moral, R. A., Hinde, J., and Demétrio, C. G. B. (2017). Half-normal plots and overdispersed models in R: the hnp package. J. Stat. Softw. 81, 1-23. doi: $10.18637 /$ jss.v081.i10

Nelder, J. A., and Wedderburn, R. W. M. (1972). Generalized linear models. J. R. Stat. Soc. Ser. A 135, 370-384. doi: 10.2307/2344614

Oliveira, D. G. P., Pauli, G., Mascarin, G. M., and Delalibera, I. (2015). A protocol for determination of conidial viability of the fungal entomopathogens Beauveria bassiana and Metarhizium anisopliae from commercial products. J. Microbiol. Methods 119, 44-52. doi: 10.1016/j.mimet.2015.09.021

Ouedraogo, A., Fargues, J., Goettel, M. S., and Lomer, C. J. (1997). Effect of temperature on vegetative growth among isolates of Metarhizium anisopliae and M. flavoviride. Mycopathologia 137, 37-43. doi: 10.1023/A:1006882621776

Paixão, F. R. S., Muniz, E. R., Barreto, L. P., Bernardo, C. C., Mascarin, G. M., Luz, C., et al. (2017). Increased heat tolerance afforded by oil-based conidial formulations of Metarhizium anisopliae and Metarhizium robertsii. Biocontrol Sci. Technol. 27, 324-337. doi: 10.1080/09583157.2017.1281380

R Core Team (2020). R: A Language and Environment for Statistical Computing. R Foundation for Statistical Computing, Vienna, Austria. Available online at: https://www.R-project.org/ (accessed on 17 December 2020).

Rangel, D. E. N., Braga, G. U. L., Anderson, A. J., and Roberts, D. W. (2005). Variability in conidial thermotolerance of Metarhizium anisopliae isolates from different geographic origins. J. Invertebr. Pathol. 88, 116-125. doi: $10.1016 /$ j.jip.2004.11.007

Rezende, J. M., Zanardo, A. B. R., Lopes, M. S., Delalibera, I., and Rehner, S. A. (2015). Phylogenetic diversity of Brazilian Metarhizium associated with sugarcane agriculture. BioControl 60, 495-505. doi: 10.1007/s10526-015-9656-5

Rigby, R. A., and Stasinopoulos, D. M. (2005). Generalized additive models for location, scale and shape. Appl. Stat. 54, 507-554. doi: 10.1111/j.1467-9876.2005.00510.x

Rocha, L. F. N., Inglis, P. W., Humber, R. A., Kipnis, A., and Luz, C. (2013). Occurrence of Metarhizium spp. in Central Brazilian soils. J. Basic Microbiol. 53, 251-259. doi: 10.1002/jobm.201100482

Sasan, R. K., and Bidochka, M. J. (2012). The insect-pathogenic fungus Metarhizium robertsii (Clavicipitaceae) is also an endophyte that stimulates plant root development. Am. J. Bot. 99, 101-107. doi: 10.3732/ajb.1100136

Solomon, K. R. (2008). Effects of ozone depletion and UV-B radiation on humans and the environment. Atmosphere-Ocean 46, 185-202. doi: 10.3137/ao. 460109

Steinwender, B. M., Enkerli, J., Widmer, F., Eilenberg, J., Kristensen, H. L., Bidochka, M. J., et al. (2015). Root isolations of Metarhizium spp. from crops reflect diversity in the soil and indicate no plant specificity. J. Invertebr. Pathol. 132, 142-148. doi: 10.1016/j.jip.2015.09.007

Steinwender, B. M., Enkerli, J., Widmer, F., Eilenberg, J., Thorup-Kristensen, K., and Meyling, N. V. (2014). Molecular diversity of the entomopathogenic fungal Metarhizium community within an agroecosystem. J. Invertebr. Pathol. 123, 6-12. doi: 10.1016/j.jip.2014.09.002

Thomas, M. B., and Jenkins, N. E. (1997). Effects of temperature on growth of Metarhizium flavoviride and virulence to the variegated grasshopper, Zonocerus variegatus. Mycol. Res. 101, 1469-1474. doi: 10.1017/S0953756297004401

Tumuhaise, V., Ekesi, S., Maniania, N. K., Tonnang, H. E. Z., Tanga, C. M., Ndegwa, P. N., et al. (2018). Temperature-dependent growth and virulence, and mass production potential of two candidate isolates of Metarhizium anisopliae (Metschnikoff) Sorokin for managing Maruca vitrata Fabricius (Lepidoptera: Crambidae) on cowpea. Afr. Entomol. 26, 73-83. doi: 10.4001/003.026.0073

Vega, F. E., Meyling, N. V., Luangsa-Ard, J. J., and Blackwell, M. (2012). "Fungal entomopathogens," in Insect Pathology. eds F. E. Vega, H. K. Kaya (London: Academic Press), 171-220. doi: 10.1016/B978-0-12-384984-7.00006-3

Vidal, C., Fargues, J., and Lacey, L. A. (1997). Intraspecific variability of Paecilomyces fumosoroseus: effect of temperature on vegetative growth. J. Invertebr. Pathol. 70, 18-26. doi: 10.1006/jipa.1997.4658

Walstad, J. D., Anderson, R. F., and Stambaugh, W. J. (1970). Effects of environmental conditions on two species of muscardine fungi (Beauveria 
bassiana and Metarrhizium anisopliae). J. Invertebr. Pathol. 16, 221-226. doi: 10.1016/0022-2011(70)90063-7

Welling, M., Nachtigall, G., and Zimmermann, G. (1994). Metarhizium spp. isolates from Madagascar: morphology and effect of high temperature on growth and infectivity to the migratory locust, Locusta migratoria. Entomophaga 39, 351-361. doi: 10.1007/BF02373040

Wyrebek, M., Huber, C., Sasan, R. K., and Bidochka, M. J. (2011). Three sympatrically occurring species of Metarhizium show plant rhizosphere specificity. Microbiology 157, 2904-2911. doi: 10.1099/mic.0.051102-0

Zimmermann, G. (2007). Review on safety of the entomopathogenic fungus Metarhizium anisopliae. Biocontrol Sci. Technol. 17, 879-920. doi: 10.1080/09583150701593963
Conflict of Interest: The authors declare that the research was conducted in the absence of any commercial or financial relationships that could be construed as a potential conflict of interest.

Copyright (๔ 2021 Couceiro, Fatoretto, Demétrio, Meyling and Delalibera. This is an open-access article distributed under the terms of the Creative Commons Attribution License (CC BY). The use, distribution or reproduction in other forums is permitted, provided the original author(s) and the copyright owner(s) are credited and that the original publication in this journal is cited, in accordance with accepted academic practice. No use, distribution or reproduction is permitted which does not comply with these terms. 